\title{
Fortification system in Valdivia, Chile: relevant Spanish colonial urban settlement expressions transferred to America
}

\author{
M. Pizzi \\ History and Heritage Institute, Faculty of Architecture and Urbanism, \\ University of Chile, Chile
}

\begin{abstract}
During the seventeenth and eighteenth centuries, the settlement of Valdivia, Chile, in Corral Bay, was the best fortified port of the Spanish Colonial domain, due to its strategic setting on the South Pacific coast. On several occasions it was devastated by natural disasters, such as earthquakes, tsunamis and fires or by human intervention of the native inhabitants or pirate sacking. It is the oldest southern city founded in 1552, today with an industrial character and as a university pole and tourist attraction.

The Spanish colonial process in Chile took place mainly inland, establishing only three main strongly fortified coastal areas in Valparaiso, Valdivia and Punta Arenas. The Royal Spanish Army, in 1645, built in Valdivia, relevant fortifications in a strategic circular system layout, including the areas of Mancera, Corral and Niebla, in order to dissuade and attack enemies, surrounding them from different flanks to guarantee the Crown's domains, especially after the Dutch occupation.

Fortresses and castles were mainly designed by the most relevant engineers of the Royal Crown, reflecting a process of cultural and technological influence transferred to America. These valuable remains, which represent the genesis of the urban settlement logic in our country, are partially protected, and administrated by several unrelated entities. The strong historical significance of these manifestations of the Spanish Colonial process has yet to be understood, enhancing the remains as part of a local and international fortification system in the New World as an opportunity for sustainable development.

Keywords: Valdivia, Mancera, Corral, Niebla, strategic fortification system, cultural and technological transference, urban settlement logic.
\end{abstract}




\section{Introduction}

In the sixteenth century, Spain starts to consolidate conquest in the American Continent, transforming its territory with a new technological, urban and scientific imprint. The development of gunpowder and arms modified the European defense model of walled urban centers. Armies and warlike equipment marked a growing power of monarchies although this meant an investment of large monetary resources in order to maintain this military structure. Spain was able to attract expert Italian military and artillery men in the generation of its defense and attack system of urban fortified settlements in the New World. A new profession, that of the military engineers who had to develop new strategies based on metallurgy instead of wood or iron.

Italian treaties on artillery such as those of Tartaglia or Terzi edited in Venice, would found an echo in the Spanish fortification texts of Luis Collado and Cristobal Lechuga, both edited in Madrid. The Italian School through Francesco di Giorgio Martini, introduced, the needed innovations which the urban defense required regarding the new circumstances with the use of bombs and cannons. Walls became thicker and lower with the application of a new general principle, in which each part of the fortification should be protected from another point, generating the Bastion fortification prototype. In this framework it is interesting to point out how the Spaniards were surprised when finding a similar approach in prehispanic fortifications such as that of Sacsahuamán protecting Cuzco (Gutiérrez [1]).

Urban centers became conditioned by geometry with little possibilities of expansion as well as having a strong control of interior spaces.

Later in the eighteenth century, artillery once more would play a fundamental role, when French engineer Belidor demonstrated that shot range was not directly proportional to the amount of gunpowder used, while others like Gribeauval, proposed new designs to provide cannon mobility.

Through the force of geometry, cities were conceived as an enclosed design generated from the square, pentagon, hexagon or octagon, later giving form during the Renaissance to the ideal city in the utopian vision.

Cities in medieval Europe grew slowly and spontaneously in time around a castle, monastery or temple where as in the New World conquerors had the need to raise settlements hastily with a preconceived image of urban space based in a strict geometrical pattern. Until the nineteenth century straight lines which facilitated the efficiency of the cannon shot was used as argument and responding to functional requirements, although related to formal an aesthetic parameters of the ideal city making fortifications attractive way beyond their specific military purpose. On the other hand the use of treaties generated repetition in different countries with little space for dramatic innovations.

We have mentioned Italians as the forefathers of the Bastion School using norms and proportions, to whom we must add the experience of the Dutch in their relation with water, experience the Spaniards used in the ports of Cadiz, Oran in Africa, and later in America. Notable is the case of Sebastián Fernández de 
Medrano, who structured the Spanish army, wrote a treaty integrating the theoretical developments of the first two centuries of bastion fortification.

The French had also important treatise writers such as De Ville, Pagan and Vauban who thought fortification design consisted of a handling of territory in which each fortification was autonomous but formed part of a defensive system.

Vauban's text was translated into Spanish in 1743 by Ignacio de Sala author of relevant fortifications in Cádiz and Cartagena de Indias. His disciples structured the Mathematics Academy in Barcelona where Spanish military engineers were trained during the eighteenth century (Gutiérrez [2]).

The oldest fortification texts which originated in Spain itself are those of Captain Cristóbal de Rojas, in the sixteenth century, Juan de Herrera's former student who by instructions of Felipe II published his first treaty in 1598 and a second one in 1613. At the same time Diego González de Medina Barba, in his treatise of 1599 adapts recommendations from European texts. The Portuguese were also prolific in treatise writing where we can mention the works of Luís Serrão Pimentel, author of Método lusitano de fortificación of the seventeen century, which had a great repercussion in vast territories dominated by Portuguese in Africa, Asia y el Brazil. In the eighteenth century, the work of Manoel de Azevedo Fortes, O engenheiro portuguez included fortification designs in Brazil.

\section{Fortifications in America}

In America, the Spanish Crown, needed to exercise dominion in an extensive territory, allowing the extraction and transport of minerals which would sustain the empire's economy and on the other hand reach far lands evangelizing the native inhabitants. Interoceanic risks were early visualized when then treasure sent by Hernán Cortés was captured by pirates and with the destruction of the Invincible Armada in 1588. Spain had to develop a double fortification system using a terrestrial strategy protecting ports by means of an articulated network of cities. In addition a floating fortification strategy was developed through an immense fleet of galleons through three main circuits: one related to the Caribbean, a second one in Magellan Strait and a third covering the route from Manila in the Philippines to Acapulco in Mexico.

\section{Fortifications in Chile}

Chile was one of the most difficult areas to conquest for the Spaniards. The native inhabitants maintained a barrier until well advanced the eighteenth century which had impeded their advancement further south. On the other hand the Pacific coast edged an enclosed ocean with connections to the Atlantic only through Panama by land or the Magellan Strait. This maritime coastline was devastated specially during the sixteenth century, by pirates and corsairs serving England, Holland and France.

During the seventeenth century, Indian Flanders (Flandes Indiano) was the name given to Chile, in his book: Historia general del reino de Chile (General 
History of the Chilean Kingdom) by historian Diego de Rosales (Madrid 1601Santiago de Chile, $\uparrow 1677$ ) when he arrived in 1629 , relating it to the European Flanders as both were scenarios of bloody battles, imprinting a fatal destiny to the Spanish conquest process (Guarda [3]). The New World became an area of the globe under constant attacks either by locals or foreigners becoming a favorable setting for the construction of fortifications by the Latin American Bastion School, as part of the Spanish Fortification School. Its main manifestations are located in the Caribbean being those expressions located in Chile, relevant examples in the South Pacific as its coastline, after crossing the Magellan Strait, served as dissuasive protection of the coasts of the Peruvian Viceroy-Royalty. Its main role was to intimidate enemies which together with the large distances between ports and the natural fury of the Pacific acted strongly as guarantors of the Spanish Crown's territories and later during the Republic of its culture and faith. The latter objective was confirmed by King Felipe II when he was urged to abandon colonization in Chile due to the high war costs implied, by reason of disseminating the Catholic Faith.

First records of fortifications in the country were those designed by Spanoqui in the sixteenth century in the Magellan Strait and later those of the Chiloé Archipelago, were the Jesuits had established evangelization missions.

Fortifications, on the other hand, became focuses of territorial expansion, with an added agricultural and commercial character in the process of colonization expressed in a civil and ecclesiastical architecture. Eighteenth century military engineers early introduced a neoclassical imprint in our architecture, conferring a stylistic seal inherited from Europe by the Republic. This is why the role of Spain is relevant in the conservation and research of this period of our history spanning from 1541 with the foundation of Santiago representing the Spanish domain, until 1826 when the Chiloe Archipelago is annexed to the new independent country during the republican period.

\section{Fortifications in Valdivia and Corral Bay}

\subsection{Geographical situation}

The Pacific Ocean extends from Alaska to Tierra del Fuego and westwards up to the Philippines, which the Castilian Crown considered its domains during three centuries. A body of water of considerable dimensions, accessible from all directions, conditions which made vulnerable its shores and thus in need of fortifications (Albi [4]). The fortification system built in Valdivia together with the Real Felipe Fortress in Callao and the San Diego Fortress in Acapulco formed the Spanish defensive axis in the South Pacific.

Valdivia, the most southern enclave of the three, is located $39^{\circ} 48^{\prime} 30^{\prime \prime} \mathrm{S}$ latitude, and $73^{\circ} 14^{\prime} 30^{\prime}$ ' $\mathrm{W}$ longitude set in the convergence of the rivers CalleCalle, Valdivia - Cau-Cau and Cruces, at a distance of $15 \mathrm{~km}$ from Corral Bay. 


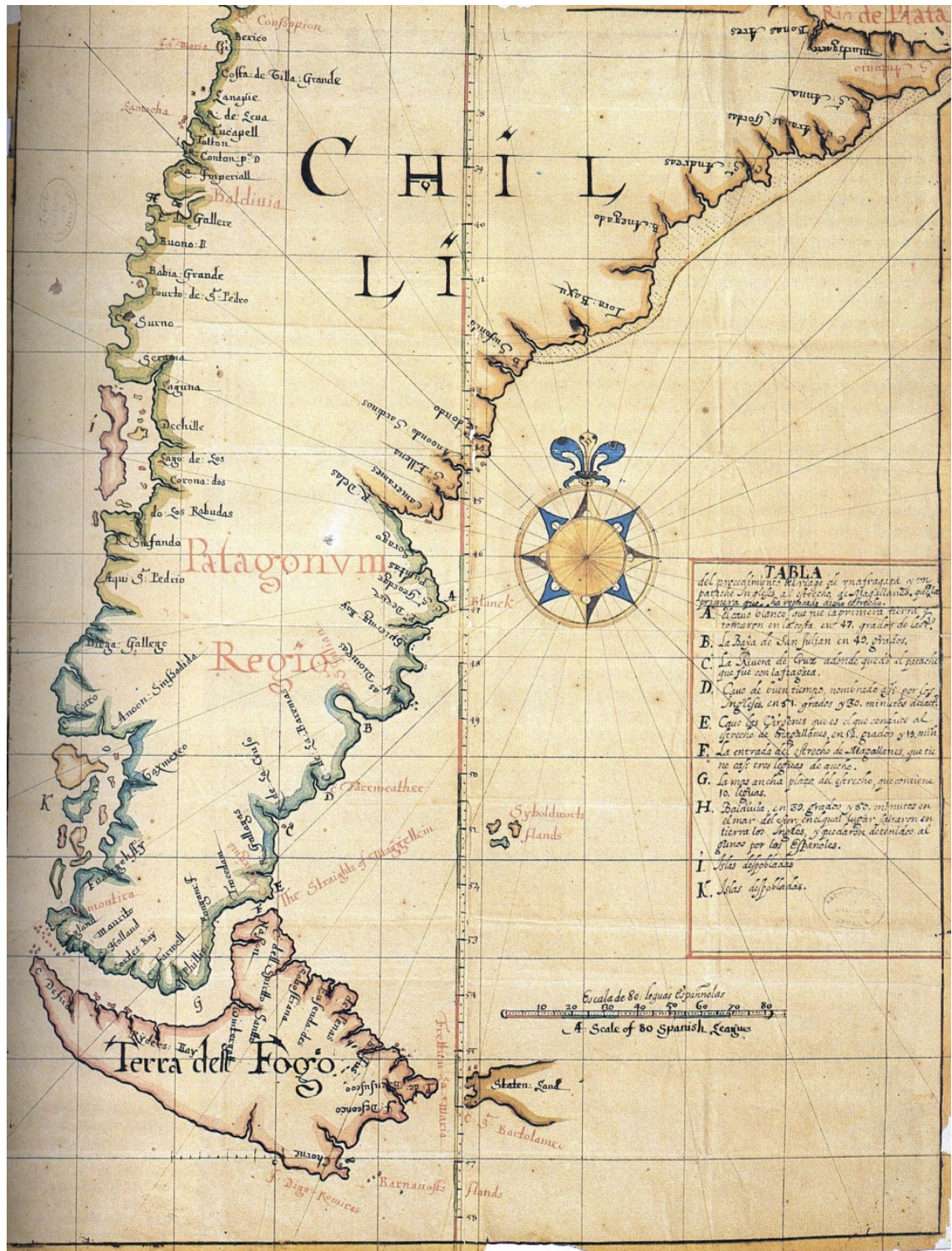

Figure 1: Map of the southern area of America sent to Spain by the ambassador in London, Count of Molina (Conde de Molina) after the trip of Narborough in 1671. Anonymous AGI, Buenos Aires 226.

In 1670 Valdivia suffered the attack of English corsairs Narborough and Swan who had to retreat due to the strength of Valdivia's fortifications. In 1712 the French engineer Frezier also admired these powerful buildings (Frezier [5]). 


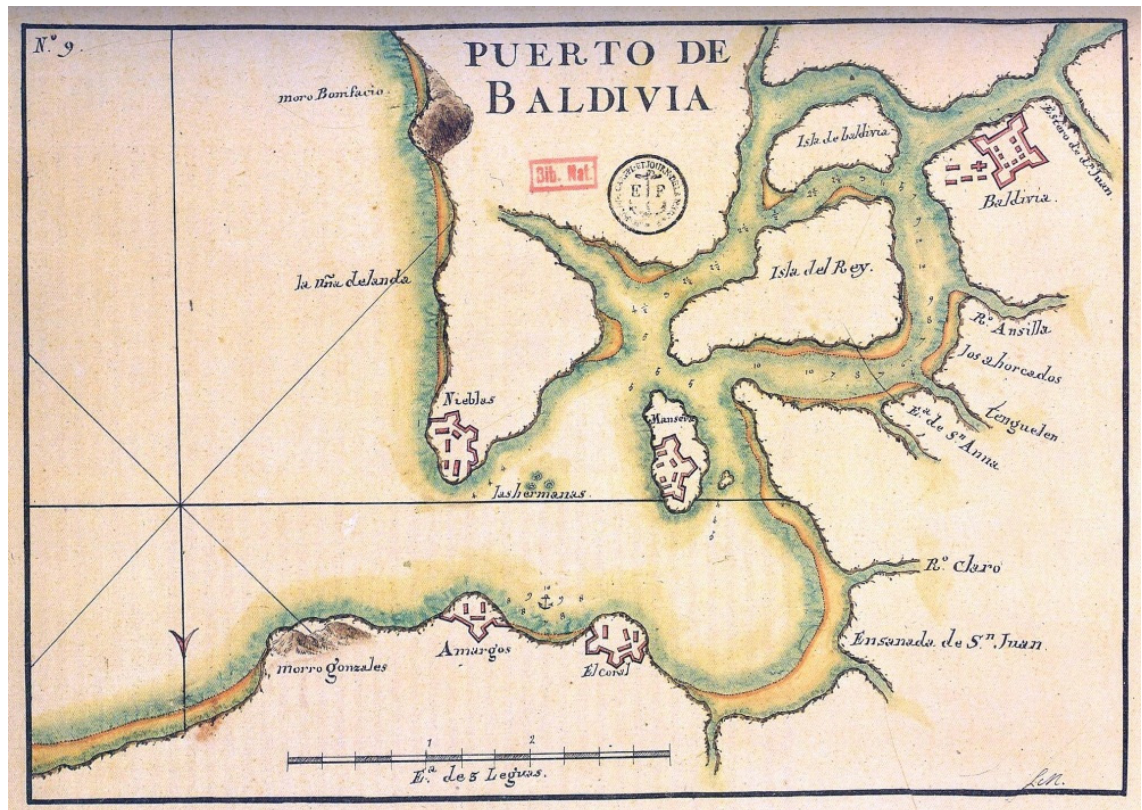

Figure 2: Port of Valdivia, c. 1700. BNP Carts et Planes Prt.169, Div. 5 piece 5, Anonymous.

\section{Main fortified areas}

The oldest bastion fortification complex remains of Chile are those of Valdivia, dating 1645 , located in a highly strategic location coinciding with the foundation of the city in 1552. The first buildings were erected a century later and further abandoned with some restoration attempts carried out during the first half of the seventeenth century until 1643, time when the Dutch occupation leaded by Hendrick Brouwer, hastened the construction of a new complex (Medina [6]).

The settlement founder, Pedro de Valdivia, (Extremadura, Spain, 1497 - Nueva Extremadura, $\uparrow 1553)$ pondered in several letters to the Emperor, the quality of its port, considered the most strategic in the South Pacific, due to its proximity to the Magellan Strait, in a distance of six navigation days, and the first refueling and supplying enclave, rich in gold, wood and commerce, attracting pirates triggering the need of defense measures (Guarda [7]).

As in all of those sixteenth century foundations, a first fortress, was built but was destroyed by the native inhabitants in 1599, building later a more extensive second structure in 1602, although most of its inhabitants died of hunger leading to its abandonment, which was to be again occupied in 1643 by the Dutch.

From then on recovery of this enclave, its repopulation and fortification became the goal of the Spanish Crown, who sent a fourteen ship fleet from Callao, Peru to which three more were added launching from Valparaíso to accomplish this purpose. The first structures were designed by Antonio Sebastián de Toledo and 
Constantino Vasconcelos built in the former Constantino Island renamed as Mancera from 1645 on after the Dutch occupation (Rosales [8]; Riso Patrón [9]).

\subsection{Mancera Castle and Baides Fort}

Due to the disposition of Corral Bay, one fortification was insufficient for its defense needing four related locations working as a circular system disposed to allow crossed fire. These four posts were located at Mancera Island, Corral, Amargos and Niebla, with minor supporting structures which in all added twelve defensive points.

Mancera, island strategically located at the center of the bay, with a hilly topography falling abruptly to the sea, possessing natural favorable conditions as a defense site. A castle named San Pedro de Alcántara, built in 1645, playing a relevant role in the defensive system, during the seventeenth century until 1780, as the central element of the political and defensive complex from where the rest of fortifications were planned. In the southern east extreme of the island, an additional fort was built, San Francisco de Baides.

From 1760 to 1769 the total population of Valdivia moved to the castle which included a main square, warehouses, a gunpowder deposit, the Governors Palace and San Antonio baroque style church and convent amongst other infrastructure. In 1774 the population returned to Valdivia, leaving the castle as a military post.

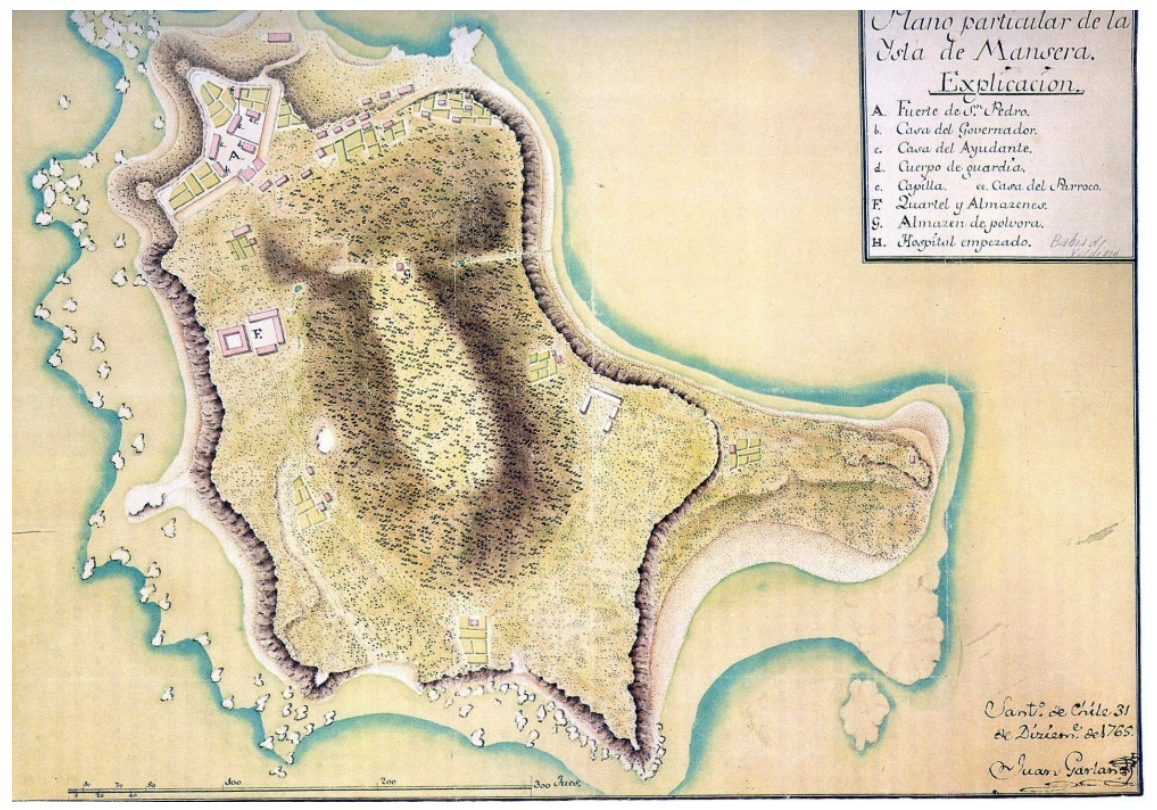

Figure 3: Plan of Mancera Island, Anonymous, 1765, SGE, Cartografía de Ultramar, Carpeta IV, p. 26, N91. 
Thomas Alexander Cochrane in 1820, in a daring operation as part of the independence war, took over the castle.

\subsection{San Sebastián de la Cruz Castle in Corral}

Castle located in the center of the port of Corral, built in 1645. During the eighteenth century the Irish engineer Juan Garland (Ireland ? - Caribbian, $\dagger 1775$ ), rebuilt it in the local stone and brick. The building was divided in three main areas: the Argolla Battery (Batería de la Argolla) in built in 1764, the Castle itself in 1765 including 21 cannonpost, and the Cortina Battery, (Batería de la Cortina) in 1767 . In 1930 its base was trespassed by a tunnel to allow the railway. Today historical representations are carried out on the site as a touristic attraction although with a lot of irresponsible treatment by visitors which are under the administration of the Corral Municipality.

\subsection{Pura y Limpia Concepción de Monfort de Lemus Castle in Niebla}

Located in Niebla, in the northern border of the bay, was built in 1671 in honor of the Peruvian Viceroy, the tenth count of Lemos, which included eighteen cannon posts. It is strategically located between the Castles of Corral and Amargos and its artillery has the largest coverage range. In the following century Juan Garland also recovered the stone walls which made it inaccessible from the sea and added a powder keg and several bullet foundation furnaces. Declared

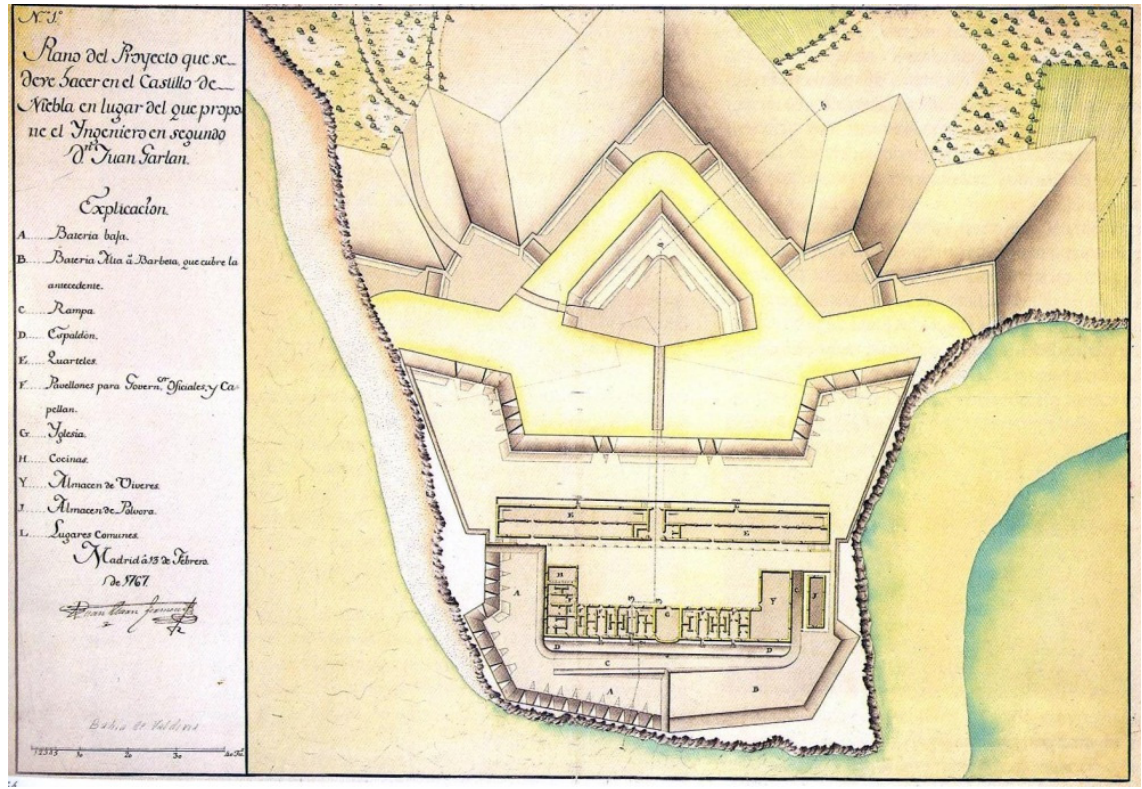

Figure 4: Plan of Niebla Castle by Juan Martín Cermeño, 1767, SGE Cartografía de Ultramar, Carpeta IV p. 31, Nº 96. 
A National Historical Monument, in 1950, it was restored in 1992, in commemoration of the fifth discovery of America Centennial celebration. It is the best conserved structure of the system, administrated by the Archives, Libraries and Museum Direction, (Dirección de Archivos, Bibliotecas y Museos DIBAM), dependent of the Ministry of Education, today used as site museum related to fortification defensive systems being the most visited by tourists.

\subsection{San Luis de Alba de Amargos Castle}

Located in the southern shore of the bay near Corral in a privately owned site which has recently been sold to the government. Built between 1655 and 1661 and rebuilt in 1679 when its fire power was duplicated to twelve cannon posts. The fort is greatly deteriorated and access is not allowed to the public.

\subsection{San Luis de Alba de Cruces Castle in Mariquina}

Only fortification remains located far from the estuary around fifty kilometers north of Valdivia. Built between 1655 and 1661, were declared National Historic Monument in 2009. It presents and important deteriorated condition, reason why visitors are not allowed and with an urgent demand for actions to assure its preservation.

\subsection{San Carlos Fortification}

Also located in the south shore of the bay, was originally built in 1763 following plans by José Antonio Birt, although only some ruins of the walls are left.

\subsection{Aguada del Inglés Fort}

Located eight kilometres away from Corral outside the bay, it was used as a base from which Lord Thomas Cochrane started the takeover of the fortification system of Valdivia during the war of independence.

\section{Problems to be solved}

One of the most negative aspects which attempts to a program of protection, restoration and revitalization of the relevant Hispanic fortifications in Corral Bay and Valdivia Estuary is that it still has to be understood as a system. At present each piece is understood independently and its management lies under a diversity of administration agents. This generates a confusing understanding of the remains as well as a lack of possible cultural and economic synergies. A strategy related to make a change in the perception towards this heritage is needed recognizing its role as a relevant phenomenon. UNESCO has launched a protective transnational initiative: The American Fortification System of the Pacific Coast. Of which the structures located in Corral Bay and the Valdivia Estuary should be important elements. 
Most structures present a deteriorated structure with not enough conservation actions or protection which is a worrying situation. Since 2005 a foundation named Castles of the End of the World, "Fundación Castillos del Fin del Mundo", with the objective of their cultural heritage management.

The area was devastated in 1960 by the worst earthquake ever registered in a magnitude of 9.5 Richter scale destroying great part of the Hispanic defensive heritage leaving only a few untouched. Until today no relevant restorations actions have been taken.

Economic and human resources would be needed to secure the facilities avoiding the constant deterioration process done by vandalism, stealing of original constructive pieces and graffiti performed by unscrupulous visitors.

The only partly economically successful activity, are the historical recreations carried out at Corral Castle by the Municipality although with no concern regarding the environmental impact on the remains. In each event the original cannons are fired, important historical pieces which should be preserved also avoiding the increasing damage on the castle. In addition, its administration body has lost interest in extending the range of cultural or artistic activities in order to promote a sustainability program. We understand that positive economical results are important, but should not prevail over cultural and heritage preservation policies.

Regarding administration of the Castle of San Luis de Alba de Cruces a double management is handled by Mariquina Municipality and Universidad Austral de Chile's, is confusing, since the role and responsibility of each body. It is not clear if any activity is done regarding this matter since fortification is in an advanced state of deterioration which has been closed to the public for this reason. What is real is that this fortification belongs to the State and is protected as a National Historic Monument considering an area of 20.876,19 $\mathrm{m}^{2}$ and because of its location in a nature sanctuary.

Although Castle San Pedro de Alcántara in Mancera and the San Luis de Alba Castle in Cruces, are under the same administration, as the Castle of San Luis de Alba, the Universidad Austral de Chile, the attention given to the three structures is totally different regarding revitalization and cultural activities and with no common related plan between them.

The Castle of Pura y Limpia Concepción de Monfort de Lemus, in Niebla, is paradoxically a different case in which there has been at least a concern for its preservation, under the administration of DIBAM. In 1992 an important preservation investment was obtained from the Spanish Government, consolidating the fortified space and creating a Site Museum preserving the essential qualities of the eighteenth century buildings. Reconstruction was ended by 1991 and opened in February 1992 with the presence of the King and Queen of Spain. There is clearly an historic, constructive and cultural proximity regarding this case and the rest of fortifications which makes unreasonable a different attitude reflecting a lack of understanding of the system as a whole.

The Castle has a museum which allows the possibility of developing additional activities of cultural vitalization, although the area where the cannons are located is endangered, being a risk for visitors. 


\section{Final conclusions}

The fortification system of Valdivia and Corral Bay, system has a strong historical value which should be understood as a network for the development of cultural and artistic activities as a potential sustainability element in the area which could attract international funding and promote the generation of new jobs.

Its architecture is attractive for different audiences, located in a natural setting close to the Pacific Ocean with great open areas for which attracts tourists.

This heritage should be understood as a support of the history of the area, which has been forgotten by the local community as well as its values as part of an internationally network related to the discovery of America and the process of colonization. Its weakness lies in the fact that each castle or fortification is administrated by different institutions, and with no involvement of the Ministry of Culture. In addition there is little information about the activities carried out and little academic research done on the area. Transport towards and between the components is almost inexistent and makes it difficult to access each of the castles and fortifications. Earthquakes as well as excessive rain are a constant menace as well and vandalism acts due to lack of protection.

We still are in debt regarding this valuable heritage, which should be recognized and revitalized as knowledge and testimony of the generation of cities in Chile and America.

\section{References}

[1] Gutiérrez, R.; Fortificaciones en Iberoamérica, Fundación Iberdrola, Ediciones El Viso, España, p. 13, 2005.

[2] Gutiérrez, R.; Op Cit, p. 20, 2005.

[3] Guarda, OSB, G.; Flandes Indiano, Las fortificaciones del Reino de Chile, 1541-1826, Ediciones Universidad Católica de Chile, p. XVIII, 1990.

[4] Albi, J.; La Defensa de las Indias (1764-1799), Instituto de Cooperación Iberoamericana, Madrid, p. 127, 1987.

[5] Frezier, A.; Relación del Viaje por el mar del sur a las costas de Chile y Perú durante los años, 1712, 1713 y 1714, translated into Spanish from 1716 French edition, Santiago, p. 4, 1902.

[6] Medina, J.T.; Relación del viaje de Hendrick Brouwer a Valdivia en 1643, Revista Chilena de Historia y Geografia, 52, p. 78, 1923.

[7] Guarda, OSB, G; Op Cit, p. 60, 2005.

[8] Rosales, D. de SJ; Historia General del Reino de Chile, Flandes Indiano, Valparaíso, III p. 272, 1877-1878.

[9] Riso Patrón, L. Diccionario Jeográfico de Chile, Imprenta Universitaria, Santiago, p. 521, 1924. 